\title{
Haemophilus parahaemolyticus, Penicillinase Positive
}

National Cancer Institute

\section{Source}

National Cancer Institute. Haemophilus parahaemolyticus, Penicillinase Positive. NCI Thesaurus. Code C123484.

Any bacterial species identified as Haemophilus parahaemolyticus that produces the enzyme penicillinase. 